\title{
An Analysis of Identification Theory in Political Fable-A Case Study of Animal Farm
}

\author{
Xin Dai \\ School of Foreign Languages, Lanzhou Jiaotong University, Lanzhou, Gansu, China \\ daixindaisydx@gmail.com
}

\begin{abstract}
Under the guidance of Burke's identification theory, this paper analyzes the speech of the old Major in the first chapter of Animal Farm from a rhetorical perspective and finds that the old Major persuades his audience, i.e., the other animals, to gain the identification from two aspects: identification by content and identification by form, thus causing the successful uprising of the animals that follows in the storyline. This study explores the embodiment of rhetoric in political fables and analyzes the rationale embedded in the fable from a new perspective, that of rhetoric.
\end{abstract}

Keywords: Rhetoric, Political fable, Identification, Burke.

\section{Introduction}

\subsection{Background}

The twentieth century witnessed a renewed interest in the study of rhetoric. Kenneth Burke is the representative of new rhetoric.

In A Rhetoric of Motives, Kenneth Burke tells that the basic function of rhetoric is through the use of words by human agents "to form attitudes or to induce actions in other human agents." He thinks that rhetoric "is rooted in an essential function of language itself, a function that is wholly realistic, and is continually born anew; the use of language as a symbolic means of inducing cooperation in beings that by nature respond to symbols." (Burke, 1969)

It was no accident that Orwell wrote Animal Farm and 1984. Orwell went to Spain at the end of 1936 to fight in the Spanish Civil War, and the Workers' Party of Marxist Unification(POUM), which had taken Orwell in, was formed by the fusion of the Trotskyist Communist Left of Spain. Orwell were thus considered "fanatical Trotskyists" and targeted by the Spanish Republican Army, which was allied with USSR governed by Joseph Stalin. When Orwell returned from Spain, he was outraged by the Spanish Republican Army' ostensibly progressive and democratic political practices and physical persecution and ideological control, and later wrote many articles to expose them. In the 1920s and 1930s, when many left-wing intellectuals in the West had hopes for the Soviet Union, Orwell, through his own experience and his knowledge of the Great Purge and a series of other events, had his own views on the nature of the Soviet Union under Stalin's rule. Orwell strengthened his belief in socialism, or exactly, the democratic socialism. Animal Farm, written in the form of a fable, was the product of this kind of thinking.

Animal Farm, a political fable by George Orwell, was first published in England on August 17, 1945. The book tells the story of a group of farm animals who, at the call of a pig, harbor a determination to rebel against man, and who wish to establish a society where animals can be equal, free and happy. However, their goal ultimately fails because although they drive out the humans, the farm ends up in the same bad state as before under the dictatorial rule of a pig named Napoleon.

This study is based on the first chapter of this fable. In the first chapter, old Major, a Middle White boar, takes the leading in calling on other animals in the farm to rebel against the domination of human and to govern the farm by themselves.

\subsection{Purpose and Significance}

In ancient Greece, rhetoric mainly served for the political ends. Throughout the analysis, we try to explore rhetorical motives in political fables.

As a fable always teaches us a moral lesson, we try to find out how to look at the lesson from the perspective of rhetoric.

It helps to provide a new perspective for the readers. And it also has practical significance for our reading and writing. The understanding of identification can help us approach the author better in reading and adapt to the readers better in writing.

\section{Theoretical Framework}

\subsection{Identification and Persuasion}

In short, identification refers to the agreement between the speaker and the listener in communication.

Burke does not mean to deny the significance of persuasion in rhetoric, but to show that identification is an important auxiliary means for speakers to succeed in persuading audiences. As he says, "Traditionally, the key term for rhetoric is not 'identification', but 'persuasion'....Our treatment, in terms of identification, is decidedly not meant as a substitute for the sound traditional approach. Rather, as we try to show, it is but an accessory to the standard lore." (Burke, 1969)

Here, we can say the difference and relation between persuasion in old rhetoric and identification in new rhetoric from the words of Burke himself. 
"If I had to sum up in one word the difference between the 'old' rhetoric and a 'new', I would reduce it to this: The key term for the old rhetoric was 'persuasion' and its stress was upon deliberate design. The key term for the 'new' rhetoric would be 'identification', which can include a partially 'unconscious' factor in appeal.” (Burke, 1951)

"As for the relation between 'identification' and 'persuasion': we might well keep it in mind that a speaker persuades an audience by the use of stylistic identifications; his act of persuasion may be for the purpose of causing the audience to identify itself with the speaker's interests; and the speaker draws on identification of interests to establish rapport between himself and his audience. So, there is no chance of our keeping apart the meanings of persuasion, identification ('consubstantiality') and communication (the nature of rhetoric as 'addressed').” (Burke, 1969)

As for the concept of "consubstantial", Burke also gives us some explanations. According to Ju (2004), Burke uses the term "consubstantiality" synonymously with "identification". In Burke's language, when one identifies himself with someone else, or with something else, he becomes consubstantial with it. "To identify A with B is to make A 'consubstantial' with B”. (Burke, 1969)

\subsection{Identification via Rhetorical Content}

According to Burke (1973), identification has three types: identification by sympathy, identification by antithesis and identification by inaccuracy. (Chang, 1998)

\section{-Identification by sympathy}

The speaker emphasizes the common feelings to establish a close relationship with the audience. We can say that when we meet a person who came from the same hometown with us, we would feel closer with him than with others.

\section{-Identification by antithesis}

It is a union formed by the fact that the speaker and listeners have a common opposition. It is true that the international anti-fascist allay which was united by China, Britain, the United States and the Soviet Union is a clear example of this kind of identification, for the four countries had a common enemy so that they grouped together at that time.

\section{-Identification by inaccuracy}

It is often manifested in people's inaccurate identification about their own situations. (Liu, 2008) For example, mistakenly regard mechanical ability as our own.

\subsection{Identification via Rhetorical Form}

Identification is not only reflected in content, but also in form. As Burke (1968) says, "Form in literature is an arousing and fulfillment of desires. A work has form in so far as one part of it leads a reader to anticipate another part, to be gratified by the sequence." Thus, in the excerpt of this fable, the form achieves identification, which evokes the inner thoughts of the listener and makes the listener anticipate the speaker's next words. In this paper, we analyze three main types of identification via form: progressive form, repetitive form and conventional form.

Progressive form is subdivided into syllogistic progression and qualitative progression. Among them, syllogistic progression is mainly realized by syllogism. For qualitative progress, we focus on "the presence of one quality prepares us for the introduction of another. Such progressions are qualitative rather than syllogistic..." (Burke, 1968). Compared with the two, syllogistic progression emphasizes "the pronounced anticipatory nature", while the qualitative progression is to "recognize its rightness after the event" (Burke, 1968). According to the Bradley University's website, "Syllogistic progression is the sequential articulation of a formally presumed argument. Qualitative progression is the sequential articulation of an unanticipated argument."

"Repetitive form is the consistent maintaining of a principle under new guises. It is restatement of the same thing in different ways." (Burke, 1968) The form of repetition is not the repetition of form, but the repetition of content. Repetition can help the speaker to emphasize what he wants to emphasize, highlight the key points, arouse the audience's feelings, influence the audience's decision-making behavior, and finally reach the identification of the speaker. According to Burke (1968), "By a varying number of details, the reader is led to feel more or less consciously the principle underlying them--he then requires that this principle be observed in the giving of further details." Also, he views repetitive form as an important way, "It is our only method of "talking on the subject"” (Burke, 1968).

"Conventional form is the expectations of a particular form prior to encountering a work. It involves the expectations that audiences bring with them to the form." (Foss et al., 2002). Any form can be conventional, and any form has its own conventional mode. For example, although the content is different, the recursive form of syllogism is unchanged; and the theme or point of view of sonnet is different, the presentation form is consistent. Moreover, the application of conventional form is usually regarded as a response to the reader's expectation. "Whereas the anticipations and gratifications of progressive and repetitive form arise during the process of reading, the expectations of conventional form may be anterior to the reading." (Burke, 1968)

\section{Analysis}

The old Major calls for other animals to revolt in the first chapter. Greatly inspired by old Major's words, the animals sang along with him the song Beasts of England that night. "They were so delighted with the song that they sang it right through five times in succession, and might have continued singing it all night if they had not been interrupted." And in the second chapter the opportunity comes in a hurry so the animals succeed in driving out the humans and prepare to manage the farm properly by themselves. Two pigs come forward to act as the animals' leaders, leading the other animals in literacy, labor and building a windmill and so on. After the conflict between the two pigs intensified, Snowball was driven out of the farm by Napoleon. However, Napoleon 
domesticated nine dog as his guards, and gradually canceled the assembly discussion session. The Seven Commandments which were inscribed on the wall drafted by all animals were gradually deleted. The pigs increasingly oppressed other animals, and there was a very obvious class division in the animal farm. Eventually, the animals find that Napoleon also like human beings can walk with two legs, so the animals failed in their goal.

\subsection{Analysis of Identification by Content in the Excerpt}

\subsubsection{Identification by Sympathy}

(1) No animal in England knows the meaning of happiness or leisure after he is a year old. No animal in England is free.

(2) Is it because this land of ours is so poor that it cannot afford a decent life to those who dwell upon it?

(3) This single farm of ours would support a dozen horses, twenty cows, hundreds of sheep - and all of them living in a comfort and a dignity that are now almost beyond our imagining.

(4) Only get rid of Man, and the produce of our labour would be our own. Almost overnight we could become rich and free.

(5) Beasts of England, beasts of Ireland,

Beasts of every land and clime,

Hearken to my joyful tidings

Of the golden future time.

In these excerpts above, the speaker old Major expresses the shared values and pursuits of all animals in the farm. From these words, we know that they want to live a decent life and live in a comfort and a dignity, with happiness and leisure, becoming rich and free, and they all believe that they have a golden future. It is by resorting to these common opinions that the speaker wins the listeners' approvals.

Therefore, it is easy for readers to understand when reading the following chapters. It is precisely because of these common pursuits that animals encourage each other and take these as their beliefs to support their hard work.

(6) Let us face it: our lives are miserable, laborious, and short. We are born, we are given just so much food as will keep the breath in our bodies, and those of us who are capable of it are forced to work to the last atom of our strength; and the very instant that our usefulness has come to an end we are slaughtered with hideous cruelty.

The speaker uses words such as "we", "us" and "our" to describe the same situation of all animals and emphasize that they share a lot in common.

This paves the way for the unity of the animals to against the enemy and their solidarity in the labour.

(7) Our labour tills the soil, our dung fertilises it, and yet there is not one of us that owns more than his bare skin. You cows that I see before me, how many thousands of gallons of milk have you given during this last year? And what has happened to that milk which should have been breeding up sturdy calves? Every drop of it has gone down the throats of our enemies. And you hens, how many eggs have you laid in this last year, and how many of those eggs ever hatched into chickens? The rest have all gone to market to bring in money for Jones and his men. And you, Clover, where are those four foals you bore, who should have been the support and pleasure of your old age? Each was sold at a year old-you will never see one of them again. In return for your four confinements and all your labour in the fields, what have you ever had except your bare rations and a stall?

(8) But no animal escapes the cruel knife in the end.

(9) To that horror we all must come-cows, pigs, hens, sheep, everyone.

The old Major's speech emphasizes the current situation of the animals, that is, working hard for no benefit. He highlights the examples of three animals, cows, whose milk is seized by man, hens, whose eggs are sold by man, and horses, whose foals are also sold by man. And instead of bringing benefits to their children, they have all the fruits of their labor and fertility taken away by human beings. By emphasizing this point, the old Major evokes a sense of anger in these three groups of animals and others, and since the animals are all in a miserable situation, this common feeling is easily established.

Besides, as in example $8 \& 9$, the old Major repeatedly mentions that all animals have a miserable future without exception, emphasizing that animals share a common destiny and strengthening their sense of unity.

\subsubsection{Identification by Antithesis}

(10) Why then do we continue in this miserable condition? Because nearly the whole of the produce of our labour is stolen from us by human beings.

(11) It is summed up in a single word-Man.

(12) Man is the only real enemy we have. Remove Man from the scene, and the root cause of hunger and overwork is abolished for ever. "Man is the only creature that consumes without producing. He does not give milk, he does not lay eggs, he is too weak to pull the plough, he cannot run fast enough to catch rabbits. Yet he is lord of all the animals.

\section{(13) Man serves the interests of no creature except himself.}

(14) I have little more to say. I merely repeat, remember always your duty of enmity towards Man and all his ways. Whatever goes upon two legs is an enemy.

In these excerpts above, the speaker old Major points out and repeatedly emphasizes that humans are their one and only enemy. He says that it is because of humans that all animals in the farm live such a bitter life. He puts humans on their opposite side, calling on all animals to fight against them. Therefore, it arises other animals' identification so that they are determined to rebel against human beings together.

It also makes it easy for the readers to understand the reasons 
that the animals eventually take action to revolt, and that the animals unite to defend themselves against their enemy when humans attempt to take back the farm in the following chapters.

\subsubsection{Identification by Inaccuracy}

(15) The soil of England is fertile, its climate is good, it is capable of affording food in abundance to an enormously greater number of animals than now inhabit it. This single farm of ours would support a dozen horses, twenty cows, hundreds of sheep - and all of them living in a comfort and a dignity that are now almost beyond our imagining.

(16) Only get rid of Man, and the produce of our labour would be our own. Almost overnight we could become rich and free.

The speaker points out the geographic advantage and state of operation of the present farm, and emphasizes that it will be no different after the rebellion, misleading the listeners that after defeating humans the fruits of their labor will be enjoyed only by themselves, and they will be able to live the life they want, a life much happier than the present one.

(17) Whatever goes upon four legs, or has wings, is a friend.

(18) And, above all, no animal must ever tyrannise over his own kind. Weak or strong, clever or simple, we are all brothers. No animal must ever kill any other animal. All animals are equal.

In addition, as the speaker says the sentences above, he makes other animals believe that everyone is equal in the animal farm, which also foreshadows the class differences among animals in the following story.

Table 1: Frequency of the three types of identification

\begin{tabular}{|l|c|c|c|}
\hline & $\begin{array}{c}\text { Identification by } \\
\text { Sympathy }\end{array}$ & $\begin{array}{c}\text { Identification by } \\
\text { Antithesis }\end{array}$ & $\begin{array}{c}\text { Identification by } \\
\text { Inaccuracy }\end{array}$ \\
\hline Frequency & 49 & 23 & 7 \\
\hline
\end{tabular}

Through the above analysis, we can find that three kinds of identifications are clearly expressed in the words of the old Major. The speaker establishes a common emotional identification with the audience through shared values and finding common ground; the speaker establishes an identification by antithesis with the audience by emphasizing that the only enemy of all animals is human beings; and the last identification that the speaker establishes in the heart of the audience through the imagination of farm life. Among them, identification by sympathy accounts for the largest proportion, and the old Major emphasizes from these different sympathies, common values and pursuits, common situation, common difficulties and common destiny, gradually piling up common emotions. This is related to the nature of animals, only in the same dilemma and have a common goal, such an appeal can be more direct to the heart, more ignite the fire of struggle and resistance dormant in the heart of animals.

\subsection{Analysis of Identification by Form in the Excerpt}

\subsubsection{Identification by Progressive Form}

Under the progressive form, we mainly analyze the identification by qualitative progress used in the selection.

On the way to his speech, the old Major found that the mouse also appeared in the field, so he motioned for everyone to vote whether the mouse was the same kind of other animals - their comrades, the result of the vote was:

(19) The vote was taken at once, and it was agreed by an overwhelming majority that rats were comrades. There were only four dissentients, the three dogs and the cat, who was afterwards discovered to have voted on both sides.

So the old Major took this result to make his point that:

(20) I have little more to say. I merely repeat, remember always your duty of enmity towards Man and all his ways. Whatever goes upon two legs is an enemy. Whatever goes upon four legs, or has wings, is a friend.

The result of the vote was not controlled by the old Major, but it was just as he wanted, so he took this opportunity to emphasize his own point of view. The presence of one quality (voting result) prepares us for the introduction of another (the old Major's view). This process is not an event that is predictable and controllable, but it still provides the conditions for the continuous expression of the speaker's subsequent arguments. Thus, it naturally helps the speaker to get the audience's identification smoothly, and enhances the sense of opposition between animals and human beings.

\subsubsection{Identification by Repetitive Form}

(21) No animal in England knows the meaning of happiness or leisure after he is a year old. No animal in England is free. The life of an animal is misery and slavery: that is the plain truth.

By repeating the phrase "No animal in England", the speaker emphasized that the animals in this farms are in the same situation and have the same tragic fate, which aroused the feelings of other animals, won their recognition and strengthened their resistance to human beings. Through the repetition of this detail, the audience will consciously feel the meaning behind the speaker's words, and then the audience will enhance their identification when the speaker gives other details.

\subsubsection{Identification by Conventional Form}

(22) Comrades, you have heard already about the strange dream that I had last night.

(23) Now, comrades, what is the nature of this life of ours?

(24) That is my message to you, comrades: Rebellion!

(25) And remember, comrades, your resolution must never falter. 
(26) And now, comrades, I will tell you about my dream of last night.

The conventional form of a speech includes an address, an opening phrase, a body, and a conclusion, even in speech fragments that appear in literature. In the excerpt of Chapter 1 of this book, as shown in example sentences 22-26, the old Major begins almost every sentence with the address "Comrades" to call the audience's attention and to get them to listen in an intimate way, indicating that they are all on the same page, thus further helping the speaker to achieve identification.

In addition, the opening and closing lines of the excerpt, i.e., example sentences 22 and 26, both refer to the old Major's dream. Since the whole uprising was triggered by this dream, without which there would have been no rally, let alone an uprising of the animals, it makes the purpose of this speech clear to the audience; and the first and last lines echo each other, so that it formally meets the expectations of the audience.

The main body of the excerpt is the key content of the speech, which is mentioned several times above, i.e. the speaker repeatedly emphasizes their common feelings, common enemy and bright future after the successful uprising in order to gain the audience's identification.

\section{Conclusion}

Based on the above analysis, we find that Burke's identification theory is very clearly reflected in the first chapter of Animal Farm. Through the appeal for the uprising of animals, we have a clear understanding of the old Major's rhetorical motive, which is to gain identification. And the old Major's motive of identification was successful, and through his appeal, the animals became enthusiastic and sang Beasts of England in unison. In the next chapters, we can see that the secret activities of the animals become frequent, because they think they have the responsibility to prepare for the rebellion, and they also formed their own ideological system-Animalism. One June, the animals could not stand the human behavior and their hunger, and finally drove the humans out of the farm.

Moreover, through the speaker's words, the readers can appreciate the truths implicated in the fable. To own the land is to have the right to speak. And for both humans and animals, labor is the only way to create wealth. Besides, readers can understand the lessons behind the fable from a new rhetorical perspective.

\section{References}

[1] Burke, Kenneth. (1951). Rhetoric-Old and New. The Journal of General Education, 5(3), 202-209.

[2] Burke, Kenneth. (1968). Conter-statement. University of California Press.

[3] Burke, Kenneth. (1969). A Rhetoric of Motives. Berkeley: University of California Press.

[4] Burke, Kenneth. (1973). "The Rhetorical Situation," in
Communication: Ethical and Moral Issues. New York: Gorden and Breach Science Publishers.

[5] Foss, Sonja K., Foss, Karen A. \& Trapp, Robert. (2002). Contemporary Perspectives on Rhetoric (Third Edition). Waveland Press.

[6] Changfu, Chang \& Baotong, Gu. (1998). Contemporary Western Rhetoric Speech and Discourse Criticism. Beijing: China Social Sciences Press.

[7] Yumei, Ju. (2012). A Study on the Core Ideas of Burke's Rhetoric-a Comparison with Modern Chinese Rhetoric. Journal of PLA University of Foreign Languages, (04), 1-6+127.

[8] Yumei, Ju. (2004). Communication as Action: Discourse Analysis from the Perspective of Burkean New Rhetoric. Doctoral Dissertation, Shanghai International Studies University, Shanghai.

[9] Li, Liu. (2008). On the Identification Theory of Burke's New Rhetoric. Social Sciences in Guangxi, (08), 175-177.

[10] Min, Yang. (2011). Penetrating the Transparency of Language: An Interpretation of the Relationships between Language and Power in Animal Farm. Foreign Literature Studies, (06), 153-158.

[11] Bradley: http://bradley.bradley.edu/ ell/burke2.html

\section{Author Profile}

Xin Dai, who received a bachelor's degree from Shandong University of Science and Technology in 2019, is now studying for a master's degree in Lanzhou Jiaotong University, majoring in translation theory and practice under the discipline of foreign linguistics and applied linguistics. 